\title{
Analisis Location Quotient Sektor Petambangan Dan Penggalian Di Kabupaten Manokwari Provinsi Papua Barat
}

\author{
Renny Cahyaningtyas ${ }^{1}$, Juanita Rosalia Horman ${ }^{2}$ \\ ${ }^{1}$ Alumni Jurusan Teknik Pertambangan, Fakultas Teknik Pertambangan dan Perminyakan, Universitas Papua \\ ${ }^{2}$ Dosen Jurusan Teknik Pertambangan, Fakultas Teknik Pertambangan dan Perminyakan, Universitas Papua
}

Permalink/DOI: https://doi.org/10.36883/jfres.v4i2.63

Received: September 2021; Accepted: September 2021; Published: September 2021

\begin{abstract}
Abstrak
Location quotient (LQ) adalah suatu teknik yang digunakan dalam menentukan suatu sektor basis di suatu daerah. Analisis ini diperlukan dalam perencanaan pembangunan wilayah yang erat kaitannya dengan kebijakan ekonomi suatu daerah. Sektor basis adalah sektor yang memiliki potensi besar dalam menentukan arah pembangunan. Tujuan penelitian ini yaitu memperkirakan atau mengidentifikasi sektor mana yang menjadi sektor basis ditinjau berdasarkan PDRB tahun 2015-2020. Dari hasil penelitian, berdasarkan PDRB terdapat 15 sektor yang menjadi sektor basis dari 17 sektor yang ada, dan dua di antaranya merupakan sektor non basis. Adapun sektor yang termasuk non basis ialah sektor pertambangan dan penggalian (minining \& quarrying), dan sektor industri pengolahan (manufacturing).
\end{abstract}

Kata kunci: Location Quotient, sektor basis, sektor non basis, PDRB

\begin{abstract}
Location quotient $(L Q)$ is a technique used in determining a base sector in an area. This analysis is needed in regional development planning which is closely related to the economic policy of a region. The basic sector is a sector that has great potential in determining the direction of development. The purpose of this study is to estimate or identify which sectors are the base sectors reviewed based on the 2015-2020 GDRP. From the results of the study, based on GDRP there are 15 sectors that are the base sector of the existing 17 sectors, and two of them are non-base sectors. The non-basic sectors include the mining and quarrying sector, and the manufacturing sector.
\end{abstract}

Keywords: location quotient, base sector, non-base sector, GDRP

How to Cite: Cahyaningtyas, R. \& Horman, J.R. (2021). Analisis Location Quotient Sektor Petambangan Dan Penggalian Di Kabupaten Manokwari Provinsi Papua. JFRES: Journal of Fiscal and Regional Economy Studies, 4(2), 48 - 52, doi: https://doi.org/10.36883/jfres.v4i2.63.

\footnotetext{
Corresponding author:

E-mail: j.horman@unipa.ac.id
} 



\section{PENDAHULUAN}

Location quotient (LQ) adalah suatu teknik yang digunakan dalam menentukan suatu sektor basis di suatu daerah. Teknik LQ ini merupakan suatu teknik yang menyajikan perbandingan relatif antara kemampuan suatu sektor di daerah yang diselidiki dengan kemampuan sektor yang sama pada daerah yang lebih luas. Teknik LQ dapat dihitung dengan 3 cara berdasarkan jenis datanya yaitu, berdasarkan PDRB, tenaga kerja dan komoditi atau produksi daerah. Pada penelitian ini yang digunakan ialah PDRB.

Sektor basis adalah suatu sektor yang mengekspor barang atau jasa keluar batas perekonomian masyarakatnya atau memasarkan barang dan jasa mereka kepada orang yang datang dari luar perbatasan perekonomian masyarakat yang bersangkutan. Sektor basis digunakan sebagai indikator yang menunjukkan sektor unggulan dari suatu lokasi (Achmad, 2019). Sektor unggulan adalah sektor atau sub sektor yang mampu mendorong kegiatan ekonomi dan menciptakan kesejahteraan di suatu daerah terutama melalui produksi, ekspor dan penciptaan lapangan pekerjaan, sehingga identifikasi sektor unggulan sangat penting terutama dalam rangka menentukan prioritas dan perencanaan pembangunan ekonomi di daerah (Tambunan, 2001).

Kebijakan ekonomi saat ini pengembangannya diarahkan pada sektor ekonomi unggulan yang erat kaitannya dengan kepentingan masyarakat luas dan terkait dengan potensi masyarakat serta sekaligus sesuai dengan sumberdaya ekonomi lokal. Peranan sektor unggulan semakin strategis, karena merupakan sektor yang mampu memberikan kontribusi yang berarti terhadap perolehan devisa. Dengan demikian analisis sektor basis ini merupakan dasar yang sangat penting dalam perencanaan pengembangan wilayah serta penentuan kebijakan ekonomi.

Pada bidang pertambangan analisis ini dapat digunakan untuk mengetahui apakah sektor pertambangan dan penggalian suatu wilayah dalam hal ini Kabupaten Manokwari Provinsi
Papua Barat merupakan suatu sektor basis atau bukan. Manokwari sebagai salah satu Kabupaten di Provinsi Papua Barat yang memiliki endapan bahan galian yang tersebar di beberapa kecamatan yang ada di Kabupaten Manokwari. Endapan bahan galian tersebut berupa Silimanit-Andalusit yang berada di Kecamatan Warmare, Batugamping yang berada di Kecamatan Warmare, Batugamping yang berada di Desa Tanahmerah Kecamatan Manokwari, Batugamping yang berada di Desa Andai Kecamatan Manokwari, dan Lempung yang berada di Desa Saori Kecamatan Manokwari (Soedirman, dkk., 2016).

\section{METODE PENELITIAN}

\section{Jenis Penelitian}

Metode penelitian yang digunakan dalam penelitian ini adalah metode penelitian kuantitatif. Metode penelitian kuantitatif merupakan metode penelitian yang berlandaskan pada filsafat positivisme, digunakan untuk analisis data bersifat kuantitatif atau statistik dengan tujuan untuk menguji hipotesa yang telah ditetapkan.

\section{Metode Analisis}

Berikut ini merupakan rumus LQ atas dasar PDRB rumus:

$\mathrm{LQ}=\frac{V i R / V R}{V i / V}$

Dimana LQ merupakan indeks kuosien lokasi, ViR merupakan nilai PDRB disektor i Kabupaten atau Kota R, VR merupakan nilai PDRB disemua sektor di Kabupaten atau Kota R, Vi adalah nilai PDRB disektor i di Provinsi atau Daerah, serta V adalah nilai PDRB disemua sektor di Provinsi atau Daerah.

Parameter untuk kuesien lokasi baik atas dasar tenaga kerja maupun PDRB adalah sebagai berikut:

1. Jika LQ $>1$, maka suatu sektor dikatakan sektor basis.

2. Jika $L Q<1$, maka suatu sektor dikatakan sektor non basis, dan

3. Jika $L Q=1$, maka tingkat spesialisasi Kabupaten sama dengan tingkat Provinsi.

Journal of Fiscal and Regional Economy Studies 


\section{Teknik Pengumpulan Data}

Studi literatur, dalam tahap ini data yang diperoleh berasal dari internet dan data sekunder. Data sekunder diperoleh dari Badan Pusat Statistik.

\section{Teknik Pengolahan Data}

Pengolahan data dilakukan setelah data PDRB lengkap ialah dengan menghitung LQ (location quotient) setiap sektor pada setiap tahun. Perhitungan LQ dilakukan dengan menggunakan Microsoft Excel.

Tabel 1. Perhitungan Nilai LQ

\begin{tabular}{|c|c|c|c|c|c|c|c|c|}
\hline \multirow{2}{*}{ No } & \multirow{2}{*}{ Sektor } & \multicolumn{5}{|c|}{ Tahun } & \multirow{2}{*}{ Rerata } & \multirow{2}{*}{ Hasil } \\
\hline & & 2016 & 2017 & 2018 & 2019 & 2020 & & \\
\hline 1 & $\begin{array}{l}\text { Pertanian, Kehutanan, } \\
\text { danPerikanan/Agriculture, Forestry \& } \\
\text { Fishing }\end{array}$ & 1,45 & 1,38 & 1,41 & 1,35 & 1,45 & 1,41 & Basis \\
\hline 2 & $\begin{array}{l}\text { Pertambangan dan Penggalian/Mining \& } \\
\text { Quarrying }\end{array}$ & 0,14 & 0,13 & 0,14 & 0,15 & 0,15 & 0,14 & Non Basis \\
\hline 3 & Industri Pengolahan/Manufacturing & 0,12 & 0,12 & 0,13 & 0,14 & 0,15 & 0,13 & Non Basis \\
\hline 4 & $\begin{array}{l}\text { Pengadaan Listrik dan Gas/Electricity \& } \\
\text { Gas }\end{array}$ & 2,53 & 2,25 & 2,27 & 2,20 & 2,33 & 2,32 & Basis \\
\hline 5 & $\begin{array}{l}\text { Pengadaan Air, Pengelolaan Sampah, } \\
\text { Limbah dan Daur Ulang/Water supply, } \\
\text { Sewerage, Waste Management } \\
\text { \&Remediation Activities }\end{array}$ & 3,10 & 2,83 & 3,05 & 3,12 & 3,27 & 3,07 & Basis \\
\hline 6 & Konstruksi/Construction & 2,12 & 1,87 & 1,87 & 1,81 & 1,50 & 1,83 & Basis \\
\hline 7 & $\begin{array}{l}\text { Perdagangan Besar dan Eceran; Reparasi } \\
\text { Mobil dan Sepeda Motor/Wholesale \& } \\
\text { Retail Trade; Repair of Motor Vehicles \& } \\
\text { Motorcycles }\end{array}$ & 2,07 & 1,92 & 1,92 & 1,81 & 2,00 & 1,94 & Basis \\
\hline 8 & $\begin{array}{l}\text { Transportasi dan } \\
\text { Pergudangan/Transportation \& Storage }\end{array}$ & 0,24 & 2,17 & 2,17 & 2,01 & 1,68 & 1,66 & Basis \\
\hline 9 & $\begin{array}{l}\text { Penyediaan Akomodasi dan Makan } \\
\text { Minum/Accomodation \& food Service } \\
\text { Activities }\end{array}$ & 2,89 & 2,66 & 2,67 & 2,62 & 2,82 & 2,73 & Basis \\
\hline 10 & $\begin{array}{l}\text { Informasi dan Komunikasi/Information } \\
\text { \&Communication }\end{array}$ & 2,55 & 2,44 & 2,36 & 2,16 & 2,18 & 2,34 & Basis \\
\hline 11 & $\begin{array}{l}\text { Jasa Keuangan dan Asuransi/Financial \& } \\
\text { Insurance Activities }\end{array}$ & 2,93 & 2,66 & 2,66 & 2,48 & 2,62 & 2,67 & Basis \\
\hline 12 & Real Estat/Real Estate Activities & 3,02 & 2,78 & 2,63 & 2,36 & 2,46 & 2,65 & Basis \\
\hline 13 & Jasa Perusahaan/Bussiness Activities & 0,24 & 2,20 & 2,19 & 2,14 & 2,12 & 1,78 & Basis \\
\hline 14 & $\begin{array}{l}\text { Administrasi Pemerintahan, Pertahanan dan } \\
\text { Jaminan Sosial Wajib/Public Administration } \\
\text { \& Defence; Compulsory Social Security }\end{array}$ & 2,17 & 1,99 & 1,90 & 1,93 & 2,19 & 2,04 & Basis \\
\hline 15 & Jasa Pendidikan/Education & 2,09 & 1,91 & 1,97 & 1,81 & 1,82 & 1,92 & Basis \\
\hline 16 & $\begin{array}{l}\text { Jasa Kesehatan dan Kegiatan Sosial/ Human } \\
\text { Health and Social Work Activities }\end{array}$ & 2,54 & 2,32 & 2,31 & 2,33 & 2,62 & 2,42 & Basis \\
\hline 17 & Jasa lainnya/Other Service Activities & 0,23 & 2,06 & 2,02 & 2,04 & 2,18 & 1,70 & Basis \\
\hline
\end{tabular}

Sumber: Data Diolah, 2021 


\section{HASIL PENELITIAN}

Diketahui nilai tambah Sektor Pertambangan dan Penggalian adalah sebagai berikut:

$\begin{array}{rll}\mathrm{ViR} & = & 153.276 .000 .000,00 \\ \mathrm{VR} & = & 5.514 .988 .000 .000,00 \\ \mathrm{Vi} & = & 11.231 .180 .000 .000,00 \\ \mathrm{~V} & = & 54.711 .270 .000 .000,00\end{array}$

Dengan demikian, maka perhitungan nilai LQ Sektor Pertambangan dan Penggalian dapat diselesaikan dengan perhitungan sebagai berikut:

$$
\begin{aligned}
& \text { LQ 2016 }=\frac{V i R / V R}{V i / V} \\
& =\frac{153.276 .000 .000,00 / 5.514 .988 .000 .000,00}{11.231 .180 .000 .000,00 / 54.711 .270 .000 .000,00} \\
& =0,14
\end{aligned}
$$

Berdasarkan perhitungan nilai LQ $<1$ dimana itu berarti pada tahun 2016 sektor pertambangan dan penggalian termasuk dalam sektor non basis di Kabupaten Manokwari.

Hasil perhitungan LQ berdasarkan PDRB tahun 2016-2020 dapat dilihat pada tabel 1.

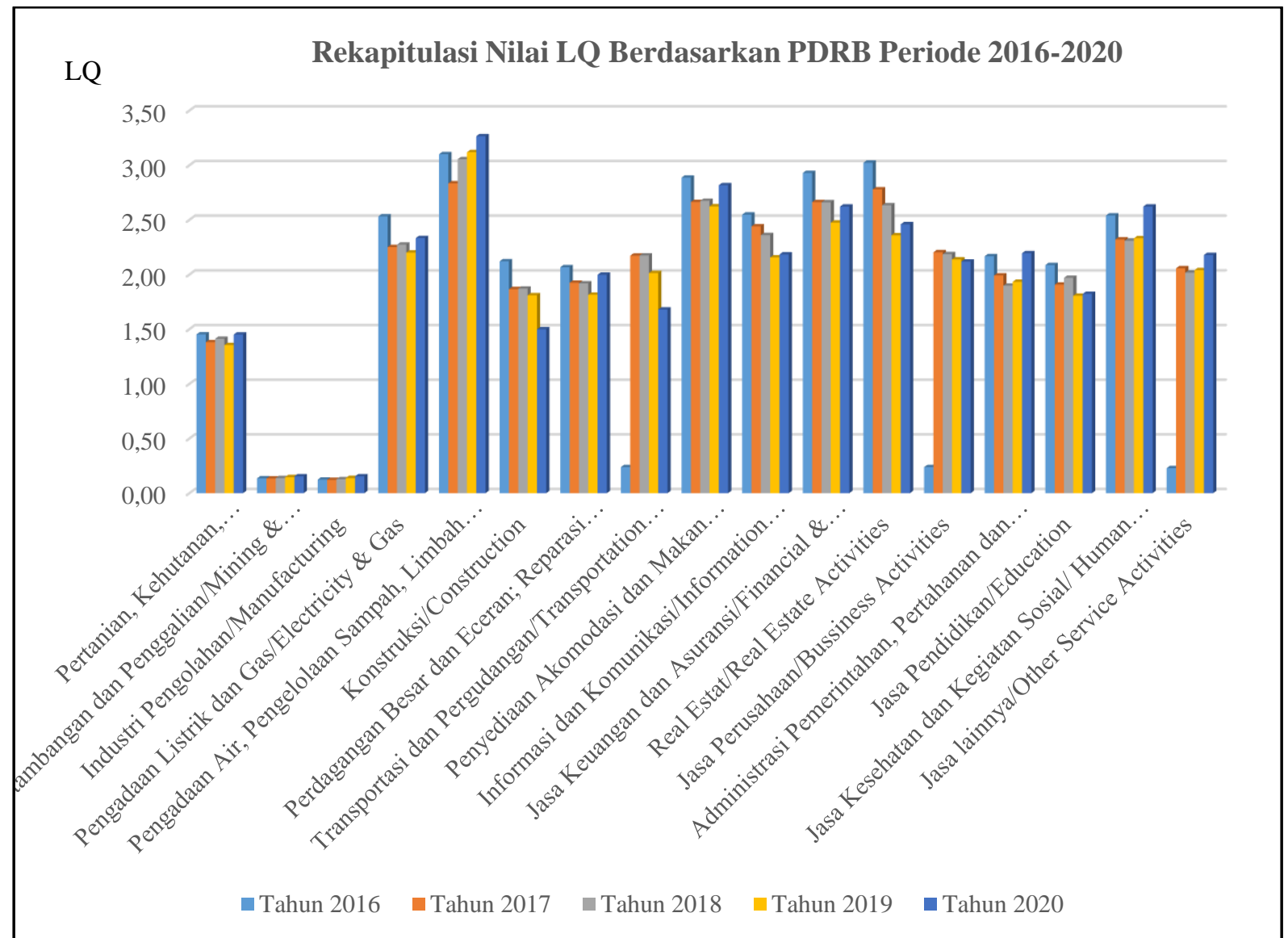

Gambar 1. Rekapitulasi Nilai LQ Berdasarkan PDRB Periode 2016-2020

Kabupaten Manokwari Provinsi Papua Barat mempunyai 17 sektor berdasarkan PDRB dengan pendekatan lapangan usaha. Pada perhitungan location quotient berdasarkan PDRB di Kabupaten Manokwari Provinsi Papua Barat ini yang dihitung ialah semua sektor. Dari perhitungan diketahui jika dari ke 17 sektor yang ada 2 diantaranya merupakan sektor non basis yaitu sektor pertambangan dan penggalian, dan sektor industri pengolahan, sedangkan 15 lainnya adalah sektor basis yaitu sektor pertanian, kehutanan dan perikanan, sektor pengadaan listrik dan gas, sektor pengadaan air, pengolahan sampah, limbah dan daur ulang, sektor konstruksi, sektor perdagangan besar dan eceran, reparasi mobil dan sepeda motor, sektor transportasi dan pergudangan, sektor penyedia akomodasi makan dan minum, sektor informasi dan komunikasi, sektor jasa keuangan, sektor real estat, sektor jasa perusahaan, sektor administrasi 
pemerintahan, pertahanan, dan jaminan sosial, sektor jasa pendidikan, sektor kesehatan dan kegiatan sosial, dan sektor jasa lainnya.
Sektor

Pertambangan

dan Penggalian/Mining \& Quarrying memiliki nilai LQ rata-rata 0,13. Ini berarti berdasarkan parameter sektor pertambangan dan penggalian merupakan sektor non basis.

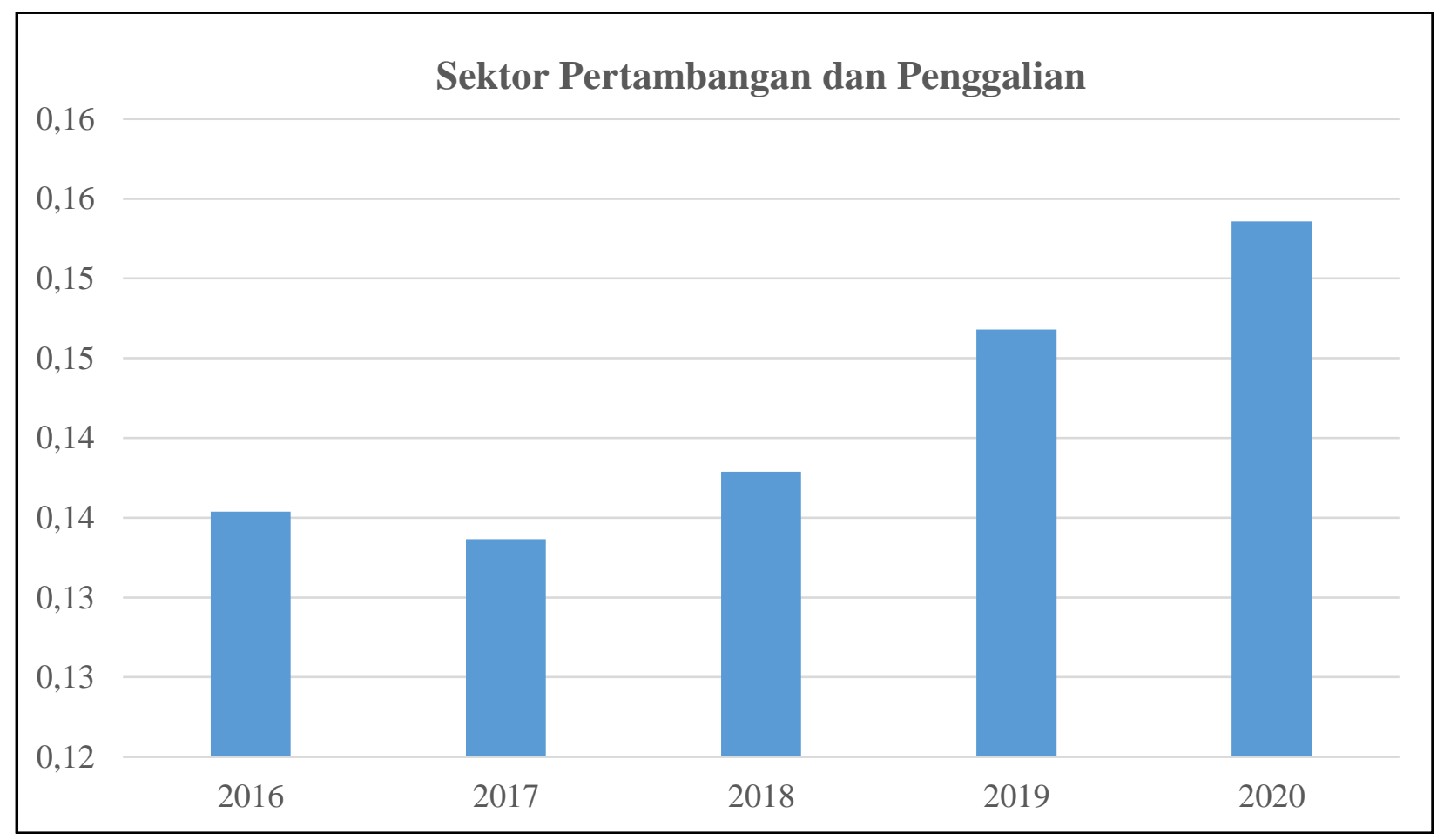

Gambar 2. Rata-rata nilai LQ Sektor Pertambangan dan Penggalian

\section{KESIMPULAN}

Berdasarkan hasil pengolahan data dan pembahasan hasil, dari ke 17 sektor yang ada 2 diantaranya merupakan sektor non basis yaitu sektor pertambangan dan penggalian, dan sektor industri pengolahan, sedangkan 15 lainnya adalah sektor basis yaitu sektor pertanian, kehutanan dan perikanan, sektor pengadaan listrik dan gas, sektor pengadaan air, pengolahan sampah, limbah dan daur ulang, sektor konstruksi, sektor perdagangan besar dan eceran, reparasi mobil dan sepeda motor, sektor transportasi dan pergudangan, sektor penyedia akomodasi makan dan minum, sektor informasi dan komunikasi, sektor jasa keuangan, sektor real estat, sektor jasa perusahaan, sektor administrasi pemerintahan, pertahanan, dan jaminan sosial, sektor jasa pendidikan, sektor kesehatan dan kegiatan sosial, dan sektor jasa lainnya.

\section{DAFTAR PUSTAKA}

Soedirman, A., dkk., 2016. Inventarisasi dan Evaluasi Mineral Non Logam Di Kabupaten Sorong dan Manokwari Provinsi Papua. http://psdg.bgl. esdm.go.id/index.php?option=com_cont ent $\&$ view $=$ article $\&$ id $=265 \&$ Itemid $=302$ (23 Mei 2021)

BPS Provinsi Papua Barat, 2019. Produk Domestik Regional Bruto Menurut Lapangan Usaha. Provinsi Papua Barat. Manokwari.

SBM Nugroho, 2004. Model Ekonomi Basis untuk Perencanaan Pembangunan Daerah. Jurnal Dinamika Pembangunan. Vol 1 No 1, pp 23 - 30.

Achmad, Zaini, 2019. Pengembangan Sektor Unggulan Di Kalimantan Timur. Deepublish. Yogyakarta. 